Vol.3 No.2 Hal. 26 - 30

September 2020
BEST JOURNAI

(Biology Education,Science \& Technolog̉y)

Fakultas Keguruan dan IImu Pendidikan
ISSN (Print) : $2614-8064$

ISSN (Online): $2654-4652$

\title{
Hak dan Kewajiban Badan Permusyawaratan Desa Dalam Membentuk Pemerintahan Desa Yang Baik
}

\author{
Syahrul Bakti Harahap
}

Universitas Muslim Nusantara Al Wasliyah

Jl.Garu II No.93 Medan Sumatera Utara

Syahrulbakti@umnaw.ac.id

\begin{abstract}
ABSTRAK
Badan Permusyawaratan Desa (BPD) adalah lembaga perwujudan demokrasi dalam penyeleggaraan pemerintahan desa. Badan permusyawaratan desa dapat dianggab sebagai parlemennya desa. Badan permusyawaratan desa merupakan lembaga baru di desa setelah otonomi daerah Indonesia. Wewenang badan permusyawaratan desa antara lain : membahas rancangan peraturan desa bersama kepala desa, melaksanakan pengawasan terhadap pelaksanaan peraturan desa dan peraturan kepala desa, mengusulkan pengangkatan dan pemberhentian kepala desa, membentuk panitia pemilihan kepala desa, menggali, menampung, menghimpun, merumuskan dan menyalurkan aspirasi masyarakat.Penelitian ini dilakukan dengan metode yuridis empiris yaitu penelitian secara langsung. Metode pengumpulan data dilakukan melalui observasi dan wawancara dengan dilengkapi angket agar data yang diperoleh lebih akurat. Populasi dan sampel dalam penelitian ini satu yakni ketua badan permusyawaratan desa, anggota badan permusyawaratan desa dan kepala desa, Desa Bengkel Kecamatan Perbaungan Kabupaten Serdang Bedagai. Analisa data dalam penelitian ini bersifat diskriptif analisis kualitatif, yaitu peneliti berusaha menggambarkan gejala sosial dengan undang-undang. Dimana ketentuan perundang-undangan dihubungkan dengan efekvitas hak dan kewaban Badan Permusyawaratan Desa dalam membentuk pemerintahan yang baik. Untuk pengambilan kesimpulan penelitian ini metode pendekatan kualitatif dengan pola pikir deduktif untuk mendapatkan gambaran Efektivitas hak dan kewajiban Badan Permusywaratan Desa dalam membentuk pemerintahan desa yang baik di Desa Bengkel Kecamatan Perbaungan Kabupaten Serdang Bedagai.
\end{abstract}

Kata Kunci : Efektivitas, Penerapan, Pasal 61 Undang-Undang No. 6 Tahun 2014

\begin{abstract}
The Village Consultative Body (BPD) is an institution that embodies democracy in the administration of village governance. The village consultative body can be called the village parliament. The village consultative body is a new institution in the village after Indonesia's regional autonomy. The powers of the village consultative body include: discussing draft village regulations with the village head, supervising the implementation of village regulations and village head regulations, proposing the appointment and dismissal of village heads, forming a village head election committee, exploring, accommodating, gathering, formulating and channeling community aspirations This research was conducted using an empirical juridical method, namely direct research. Methods of data collection are carried out through observation and interviews with questionnaires so that the data obtained is more accurate. The population and sample in this study were one, namely the head of the village consultative body, members of the village consultative body and the village head, Bengkel Village, Perbaungan District, Serdang Bedagai Regency. The data analysis in this research is descriptive qualitative analysis, that is, the researcher tries to describe social symptoms by means of laws. Where the statutory provisions are related to the effectiveness of the rights and responsibilities of the Village Consultative Body in forming good governance. To draw the conclusions of this study, a qualitative approach method with a deductive mindset to get a picture of the effectiveness of the rights and obligations of the Village Consultative Body in forming good village governance in Bengkel Village, Perbaungan District, Serdang Bedagai Regency. Keywords : Climate factors; amylose synthesis; rice quality; temperature changes; the enzyme GBSS1
\end{abstract}

Keywords : Effectiveness, Application, Article 61 of Law no. 6 of 2014 
Harahap SB : Hak dan Kewajiban Badan Permusyawaratan Desa DAlam Membentuk Pemerintahan Desa Yang Baik.

\section{PENDAHULUAN}

\section{Latar Belakang}

Setelah perubahan Undang-Undang Dasar Negara Kesatuan Republik Indonesia tahun 1945, pengaturan desa atau yang disebut dengan nama lain, dari segi pemerintahannya mengacu pada ketentuan Pasal 18 Ayat (7) yang menegaskan bahwa "Susunan dan tatacara pemerintahan daerah diatur dalam Undang-Undang". Hal itu berarti bahwa Pasal 18 Ayat (7) Undang-Undang Dasar Negara Kesatuan Republik Indonesia tahun 1945 membuka kemungkinan adanya susunan pemerintahan dalam sistem pemerintahan Indonesia.Desa adalah desa dan desa adat atau yang disebut dengan nama lain, selanjutnya disebut desa, adalah kesatuan masyarakat hukum yang memiliki batas wilayah yang berwenang untuk mengatur dan mengurus urusan pemerintahan, kepentingan masyarakat setempat berdasarkan prakarsa masyarakat, hak asal-usul, dan/atau hak tradisional yang diakui dan dihormati dalam sistem pemerintahan Negara Kesatuan Repulik Indonesia (Pasal 1 Ayat (1) Undang-Undang No. 6 tahun 2014).Sejarah pengaturan desa telah ditetapkan beberapa pengaturan desa, yaitu Undang-Undang No. 22 tahun 1948, tentang pokok pemerintahan daerah, Undang-Undang No. 1 tahun 1957 tentang pokok-pokok pemerintahan daerah, Undang-Undang No. 18 tahun 1965, tentang pokok-pokok pemerintahan daerah UndangUndang No. 19 tahun 1965 tentang desa praja sebagai bentuk peralihan untuk mempercepat terbentuknya daerah tingkat III di seluruh wilayah Republik Indonesia, Undang-Undang No. 5 tahun 1974 tentang pokok-pokok pemerintahan di daerah, Undang-Undang No. 5 tahun 1979 tentang pemerintahan desa, Undang-Undang No. 22 tahun 1999 tentang pemerintahan daerah, dan terakhir Undang-Undang No. 32 tahun 2004 tentang pemerintahan daerah. Kedudukan desa tercermin dalam Pasal 2 dan Pasal 5 Undang-Undang No. 6 tahun 2014, sebagai berikut: "Penyelenggaraan pemerintahan desa, pelaksanaan pembangunan desa, pembinaan kemasyarakatan desa, dan pemberdayaan masyarakat desa berdasarkan Pancasila, Undang-Undang Dasar Negara Republik Indonesia tahun 1945, Negara Kesatuan Republik Indonesia (NKRI), dan Bhinneka Tunggal Ika”. Ketentuan di atas menegaskan kedudukan desa sebagai bagian dari pemerintahan daerah. Lahirnya Undang-Undang desa No. 6 tahun 2014 tentang Desa mengembangkan paradigma dan konsep baru kebijakan tata kelola desa secara nasional. Undang-Undang desa ini tidak lagi menempatkan desa sebagai latar belakang Indonesia, tetapi halaman depan Indonesia. Undang-Undang desa yang disahkan pada akhir tahun 2014 lalu juga mengembangkan prinsip keberagaman, mengedepankan asas rekognisi dan subsidaritas desa. Lain dari pada itu, Undang-Undang desa ini mengangkat harkat dan kedaulatan desa yang selama ini terpinggirkan karena didudukkan pada posisi subnasional pada hal desa pada hakikatnya adalah identitas bangsa yang membentuk Negara Kesatuan Republik Indonesia..

\section{Perumusan Masalah}

Badan Permusyawaratan Desa (BPD) adalah lembaga perwujudan demokrasi dalam penyeleggaraan pemerintahan desa. Badan permusyawaratan desa dapat dianggap sebagai parlemnya desa. Badan permusyawaratan desa merupakan lembaga baru di desa setelah otonomi daerha Indonesia. Wewenang badan permusyawaratan desa antara lain : membahas rancangan peraturan desa bersama kepala desa, melaksanakan pengawasan terhadap pelaksanaan peraturan desa dan peraturan kepala desa, mengusulkan pengangkatan dan pemberhentian kepala desa, membentuk panitia pemilihan kepala desa, menggali, menampung, menghimpun, merumuskan dan menyalurkan aspirasi masyarakat.

\section{Tujuan Penelitian}

Untuk mendapatkan hasil dimana berdasarkan hasil survey awal yang dilakukan penulis pada tanggal 3 Agustus 2017, penulis melakukan wawancara singkat dengan ketua badan 
Harahap SB : Hak dan Kewajiban Badan Permusyawaratan Desa DAlam Membentuk Pemerintahan Desa Yang Baik.

permusyawaratan desa, di desa Bahal Batu menyampaikan bahwa di desa sangat sulit mengefektifkan peran badan permusyawaratan desa, sehingga sampai sekarang badan permusyawaratan desa, di desa kurang efektif. Seiring dengan hal tersebut berdasarkan keterangan ketua badan permusyawaratan desa sering usul dari badan permusyawaratan desa kurang di perhatikan

\section{Manfaat Penelitian}

Kajian ini akan memberikan manfaat dalam pemecahan masalah diatas. Berdasarkan uraian di atas, terlihat bahwa salah satu permasalahan yang menonjol di desa, tentang hak dan kewajiban badan permusyawaratan desa. Sehingga penulis berminat melakukan suatu penelitian dengan Judul "Efektivitas Hak dan Kewajiban Badan Permusyawaratan Desa Dalam Membentuk Pemerintahan Desa yang Baik di Desa Bahal Batu Kecamatan Barumun Tengah Kabupaten Padang Lawas".

\section{METODE PENELITIAN}

Penelitian ini dilakukan dengan rancangan yuridis empiris yaitu penelitian secara langsung. Penelitian tentang efektivitas hukum dimaksud untuk menelaah apakah sebuah peratuan perundang-undanagan berlaku atau tidak apakah das sollen (ideal hukum, law in books) dapat terlaksana dalam wujud das sein (kenyataan, realitas hukum, law in action). Realitas hukum adalah perilaku atau sikap seseorang terhadap kaidah hukum pada penelitian terhadap efektipitas hukum seseorang tidak hanya menetapkan tujuan perundang-undangan tetapi juga perlu memperhatikan hal-hal sebagai berikut:

1. Perilaku yang diamati adalah prilaku nyata

2. Perbandingan perilaku yang diatur dalam hukum dengan keadaan jika prilaku tidak diatur didalam hukum

3. Jangka waktu pengamatan yang wajar dan perlu dikemukaakan kondisi-kondisi objek yang diamati

4.Mempertimbangkan tingkat kesadaran pelaku

Metode pengumpulan data dilakukan melalui observasi dan wawancara dengan dilengkapi angket agar data yang diperoleh lebih akurat. Populasi dan sampel dalam penelitian ini adalah ketua BPD, anggota BPD, Kepala Desa, Bengkel Kecamatan Perbungan Kabupaten Serdang bedagai

\section{HASIL DAN PEMBAHASAN}

Hak dan Tanggung kewajiban Badan Permusyawaratn Desa (BPD) dalam Membentuk Pemerintahan Desa yang Baik. Badan permusyawaratan desa berhak menyusun peraturan tata tertib badan permusyawaratan desa (Pasal 60, UU. No. 6 tahun 2014). Dalam melakukan permusyawaratan tersebut anggota badan permusyawaratan desa, berhak menyatakan pendapat atas penyelenggaraan pemerintahan desa, pelaksanaan pembangunan desa, pembinaan kemasyarakatan desa, dan pemberdayaan masyarakat desa, mendapat biaya operasional dalam pelaksanaan tugas dan fungsinya dari anggaran pendapatan dan belanja desa (Pasal 61 UU. No. 6 tahun 2014). Anggota badan permusyawaratan desa berhak untuk, mengajukan usul rancangan peraturan desa, mengajukan pertanyaan, menyampaikan usul dan/atau pendapat, memilih dan dipih, mendapat tunjangan dari anggaran pendapatan dan belanja desa (Pasal 62 UU. No. 6 tahun 2014). Kewajiban badan permusyawaratan desa berdasarkan Undang-Undang No. 6 tahun 2014 tentang pemerintahan desa adalah sebagai berikut:

1. Menyerap, menampung, menghimpun, dan menindaklanjuti aspirasi masyarakat desa. 
Harahap SB : Hak dan Kewajiban Badan Permusyawaratan Desa DAlam Membentuk Pemerintahan Desa Yang Baik.

2. Mendahulukan kepentingan umum di atas kepentingan pribadi, kelompok, dan/atau golongan.

3. Tidak melakukan korupsi, kolusi, dan nepotisme, menerima uang, barang, dan/atau jasa dari pihak lain yang dapat memengaruhi keputusan atau tindakan yang akan dilakukannya.

4. Menyalahgunakan wewenang.

5. Melanggar sumpah/janji jabatan.

6. Merangkap jabatan sebagai Kepala Desa dan perangkat Desa.

7. Merangkap sebagai anggota Dewan Perwakilan Rakyat Republik Indonesia, Dewan Perwakilan Daerah Republik Indonesia, Dewan Perwakilan Rakyat Daerah Provinsi atau Dewan Perwakilan Rakyat Daerah Kabupaten/Kota, dan jabatan lain yang ditentukan dalam peraturan perundangan-undangan.

8. Sebagai pelaksana proyek desa.

9. Menjadi pengurus partai politik.

10. Menjadi anggota dan/atau pengurus organisasi terlara

Bedasarkan hasil penelitian yang dilkukan oleh penulis, Penulis melakukan wawancara dengan Ketua dan Angggota Badan Permusyawaratan Desa (BPD), sebagai parlemennya desa menurut Undang-undang N0. 12 Tahun 2014, tentang pemerintahan Desa. Ketua Badan Permusyawaratn Desa tidak, mengetahui tentang Undang-Undang No : 6 Tahun 2014. Kemudian penulis mengajukan pertanyaan tentang Hak dan Kewajiban BPD, baik Ketua maupun anggota BPD, tidak memahami. Sehinnga hak dan kewajiban BPD di desa Bengkel, Kecamatan Perbaungan, Kabupaten Serdang Bedagai tidak efektif, karena Pemahaman Ketua maupun anggota BPD, tentang fungsi dan peran BPD dalam membentuk pemerintahan desa yang baik tidak efektif.

\section{KESIMPULAN}

Kesimpulan yang dapat ditarik dari pengolahan dan pembahasan data adalah sebagai berikut

1. Bahwa penerapan hak dan kewajiban badan permusyawaratan desa dalam membuat peraturan desa di Desa Bengkel Kecamatan Perbaungan Kabupaten Serdang Bedagai kurang efektif .

2.Berdasarkan penelitianyang dilakukan penulis peranan Bada Permusyawaratan Desa Bengkel Kecamatan Perbaungan Kabupaten Serdang Bedagai, Baik ketua BPD maupun Anggota BPD, kurang memahami hak dan kewajibannya dalam membentuk pemerintahan desa yang baik.

\section{DAFTAR PUSTAKA}

Borni Kurniawan, 2015, Desa Mandiri Desa Membangun, Kementerian Desa Pembangunan daerah Tertinggal dan Transimigrasi, Jakarta.

Kaelan MS, 2010, Pendidikan Pancasila, Paradigma, Yogyakarta.

Lili Rasidji dan Liza Sonia Rasidji, 2012, Dasar-Dasar Filsafat dan Teori Hukum, Citra Aditya Bakti, Bandung.

M. Silahuddin, 2015, Kewenangan Desa dan Regulasi Desa, Kementerian Desa dan Pembangunan Daerah Tertinggal dan Transimigrasi Republik Indonesia. Jakarta.

Moch Soffa Ihsan, 2015, Ketahanan Masyarakat Desa, Kementerian Desa Daerah Tertinggal dan Transimigrasi, Jakarta.

Rachmad Baro, 2016, Metode Penelitian Hukum Non Doktrinal, CV. Budi Utama, Yogyakarta.

Ridwan HR, 2013, Hukum Administrasi Negara, PT. Raja Grapindo Persada, Jakarta. 
Harahap SB : Hak dan Kewajiban Badan Permusyawaratan Desa DAlam Membentuk Pemerintahan Desa Yang Baik.

Tim Visi Yustisia, 2015, Undang-Undang No. 6 tahun 2014 Tentang Desa dan Peraturan terkait, Visimedia.

Zainuddin Ali, 2012, Sosiologi Hukum, Sinar grafia, Jakarta.

Http://sugiantogeografis, Wordpress.com/Pengertian desa dan kota. Diakses tanggal 12 Agustus 2017.

Http://www.scrib.com.doc/59668084/Teori Sistem Hukum, Diakses tanggal 02 Agustus 2017

\begin{tabular}{|l|l|l|l|}
\hline Accepted Date & Revised Date & Decided Date & Accepted to Publish \\
\hline 04 Juli 2020 & 07 Juli 2020 & 10 Agustus 2020 & Ya \\
\hline
\end{tabular}

